\title{
INTRODUCTION TO SPECIAL ISSUE OF CRIMEANTHROP: CRIMINAL JUSTICE, WILDLIFE CONSERVATION AND ANIMAL RIGHTS IN THE ANTHROPOCENE
}

\author{
RAGNHILD SOLLUND \\ Professor \\ Department of Criminology and Sociology of Law \\ University of Oslo (Norway) \\ ragnhild.sollund@jus.uio.no
}

\section{INTRODUCTION TO THE SPECIAL ISSUE}

This issue of Revista Catalana de Dret Ambiental, [The Catalan Journal of Environmental Law] is dedicated to present findings from research carried out as part of the international research project: Criminal Justice, Wildlife Conservation and Animal Rights in the Anthropocene [CRIMEANTHROP], which is located at the University of Oslo, Dept. of Criminology and Sociology of Law. It is fully funded by the Research Council Norway and runs for four years ${ }^{1}$. The project includes research in Norway as the main research location (3 case studies), with supporting case studies from UK ( 1 case study), Germany ( 1 case study) and Spain (1 case study). Its purpose is to investigate the implementation and law enforcement of two central wildlife conservation conventions, CITES$^{2}$ (Convention on International Trade in Endangered Species of Wild Fauna and Flora) and the Bern convention ${ }^{3}$ (The Convention on the Conservation of European Wildlife and Natural Habitats in these

\footnotetext{
${ }^{1}$ FRIPRO, project number 289285.

${ }^{2}$ https://cites.org/eng

3 https://www.coe.int/en/web/bern-convention? sm au =iVVtWnJSVsMSFDZ5
} 
four countries from a cross disciplinary approach. The partners of CRIMEANTHROP have background in law (Teresa Fajardo del Castillo and David Rodriguez Goyes, in political science (Christoph Stefes) and in criminology (Ragnhild Sollund, D.R. Goyes, Martine Synnøve Bergesen Lie and Tanya Wyatt). CRIMEANTHROP is situated within the ground-breaking, interdisciplinary field of green criminology.

This research field relies on social and natural sciences and philosophical approaches to assess harms of human impact on the natural world, rather than focussing only on crimes. ${ }^{4}$ CRIMEANTHROP contributes to, contextualizes and investigates the ideals, philosophies and practices related to justice and rights that are the theoretical core of green criminology. An important goal is to further theorise and contribute to the positioning of green criminology, through an open grounded theory approach. ${ }^{5}$

Green criminology incorporates a central concern for animal welfare and harms and crimes against the environment. Central perspectives in this approach are; Speciesism; the central aspect of the Anthropocene, which is an analytical tool to discuss the human-wildlife relationship and to what extent wildlife should be "managed"; 6 Ecological citizenship and ecological justice; concepts which acknowledge that humans are merely one component of complex ecosystems that should have rights to be preserved for their own sake; Animal rights and species justice; concepts that identify environmental harm in relation to the place of nonhuman animals within environments and their intrinsic right to not suffer abuse,

\footnotetext{
${ }^{4}$ See e.g. BEIRNE, Piers. For a nonspeciesist criminology: Animal abuse as an object of study. Criminology, 1999 37(1), 117-148, BEIRNE, Piers., \& SOUTH, Nigel. Approaching green criminology. In P. Beirne \& N. South (Eds.), Issues in green criminology: Confronting harms against environments, humanity, and other animals (pp. xiii-xxii). 2007. Cullompton, UK: Willan Publishing, BENTON, Ted. Rights and justice on a shared planet: More rights or new relations. Theoretical Criminology, 1998. 2(2), 149-175, HALSEY, Mark; WHITE, Rob. Crime, ecophilosophy and environmental harm. Theoretical criminology, 1998, 2.3: 345-371, SOLLUND, Ragnhild (ed.). Green harms and crimes: Critical criminology in a changing world. Springer, 2015, WHITE, Rob. Environmental harm: An eco-justice perspective. Policy Press, 2013.

5 STRAUSS, Anselm., \& CORBIN, Juliet. (1994). Grounded theory methodology. Handbook of qualitative research, 17, 273-285.

6 See e.g. NIBERT, David. Animal rights/human rights: Entanglements of oppression and liberation. Rowman \& Littlefield Publishers, 2002, REGAN, Tom. (2010). The case for animal rights. Berkeley: University of California Press, SINGER, P. (1995). Animal liberation. New York: Random House.
} 
whether this be "one-on-one harm, institutionalised harm or harm arising from human actions that affect climates and environments on a global scale." While these concepts are central in the overall rationale of CRIMEANTHROP, each individual researcher determines what empirical and theoretical angles that additionally best serve to illuminate the research agenda of each specific case study, of which parts are presented jointly for the first time in this special issue. Together these articles constitute the first part of a broad picture of the theoretical philosophical, legal and criminological sides to the pertinent concerns relating to the increasing loss of wildlife and wildlife conservation at a global scale, exemplified with the case studies from Norway, Germany, UK and Spain.

\section{BACKGROUND TO CRIMEANTHROP AND THE SPECIAL ISSUE}

The present geological era is referred to as the Anthropocene ${ }^{8}$, an epoch marked by the significant impact humans have had on the environment. This is a highly relevant term for this research. The 2020 Living Planet Index records a decline of $68 \%$ in average wildife population abundance since 1970, and humans have played a major role in this. Human impact on biodiversity on land, in oceans, and in the atmosphere has not only caused the extinction of many species, but has altered the world's topography, produced climate change, and contributed profoundly to the insecurity of all earth's species. ${ }^{9}$ Nonhuman species lose their habitats, human migration is on the rise, and conflicts between humans and large predators have escalated: large predators are barely surviving in Europe's fragmented ecosystems. With the expansion of human reach and our growing consumption of earth's resources, wildlife is also being exploited for an increasing range of reasons: e.g. to

\footnotetext{
7 WHITE, Rob. Environmental harm: An eco-justice perspective. Policy Press, 2013.31.

${ }^{8}$ CRUTZEN, Paul. J. The anthropocene. 2002. Journal de pyhisique 12, 1-5,

SOLLUND, Ragnhild., TØNNESSEN, Morten, \& LARSEN, Guri. Hvem er villest $i$ landet her? Råskap mot dyr og natur i antropocen, menneskets tidsalder. Oslo: Spartacus SAP, 2013,

SOUTH, Nigel. (2015). Anticipating the Anthropocene and greening criminology. Criminology \& Criminal Justice, 15(3), 270-276.

9 AGNEW, Robert. (Dire forecast: A theoretical model of the impact of climate change on crime. Theoretical Criminology, 2012).16(1),21-42, HARARI, Yuval Noah. Sapiens: A brief history of humankind. London: Vintage Books,2015. SHEARING, Clifford. (2015).Criminology and the anthropocene. Criminology and Criminal Justice, 15(3), 255-269.
} 
serve as food, ornamentation, medicinal products, pets, entertainment and status symbols. ${ }^{10}$

Largely, economic growth and concomitant consumerism are causing the anthropogenic destruction of nature and the exploitation and marginalisation of wildlife. ${ }^{11}$ This is evident in the illegal wildlife trade (IWT) with its involvement of impoverished locals, middlemen, and organised crime ${ }^{12}$. Consumerism also interplays with predator management evinced by conflicts in wildlife management: politicised wildlife management goals and the interests of e.g. farmers, hunters, and forest owners clash with the interests of e.g. environmentalists and animal rights advocates to protect endangered species, encourage their resettlement, and expand their natural habitats. Everything considered, consumerism as a prevalent value may be hard to combat even in the current awareness of environmental destruction.

While wildlife use and conflicts between humans and large predators have deep historical roots, the causes of the pressure on endangered animal species are seldom analysed together or in light of the international conventions designed to protect wildlife. ${ }^{13}$ To examine the conventions is an important part of this research and this will contribute towards exploring their capacity to promote environmental education, awareness of animal rights, ecosystemic approaches and species protection, as well as best practices.

It was not until the 1960s, with the rise of environmental movements, that nature management-not only use of natural resources-became of concern to

\footnotetext{
10 See e.g. Schneider, Jacqueline L.. (2012). Sold into extinction: The global trade in endangered species. Santa Barbara, CA: Praeger, SOLLUND Ragnhild, MAHER Jennifer (2015) Illegal wildlife trade. A case study on illegal wildlife trade in the United Kingdom, Norway, Colombia and Brazil. Report produced as part of EFFACE. Available at: http://efface.eu/illegalwildlife-trade-case-studyreport-illegal-wildlife-trade-united-kingdom-norway-colombia-and\#overlaycontext=case-studies Accessed 21 April 2021, SOLLUND, Ragnhild. The crimes of wildlife trafficking. Issues of justice, legality and morality. London and New York: Routledge, 2019, VAN UHM, Daan Uncovering the illegal wildlife trade: In the world of poachers, smugglers and traders. New York: Springer, 2016, WYATT, Tanya. Wildlife trafficking: A deconstruction of the crime, the victims and the offenders. Basingstoke, UK: Palgrave, 2013

11 E.g. STRETESKY, Paul. B., LONG, Michael. A., \& LYNCH, Michael. J. The treadmill of crime: Political economy and green criminology. Routledge, 2013)

12 (European Commission 2014, SOLLUND, R. 2019, VAN UHM, D. 2016, WYATT, T. 2013)

${ }_{13}$ (but see Trouwborst 2010, 2015, Hutton \& Dickson 2000; Wyatt 2021).
} 
governments. Trade in many endangered species had become unsustainable, and CITES was implemented in order to preserve natural resources and income for nations that relied on wildlife trade. ${ }^{14}$

Parties to CITES $^{15}$ are required to adopt their own domestic legislation to ensure implementation and create the necessary administrative infrastructure to monitor compliance. In Norway, CITES is implemented through the CITES regulation (Lovdata 2002) and in all EU Member States, through the European Regulation on CITES (European Commission 2010). Like CITES, the Bern Convention protects endangered fauna and flora, with a special emphasis on habitat protection and biodiversity. The Convention is implemented through the Emerald Network of the Council of Europe, which converges with the EU Natura 2000 network of core breeding and resting sites for rare and threatened species. All case study countries in this project, Norway, the UK, Germany and Spain, are bound by CITES and the Bern convention.

The endangering and loss of large predators in Europe was largely due to extinction policies, whereby the aim was to get rid of the large predators, e.g. in Spain and in Norway where hunting wolves, lynx, bears, golden eagles and wolverines was encouraged by state paid bounties until the 1970s.

The last decades have witnessed a return of large predators in many European countries, including Norway, Germany and Spain, suggesting the Bern Convention has had positive effects. One cannot underestimate the practical significance of protecting large endangered predators since the killing of them, whether legal or illegal, has the greatest impact on their number. ${ }^{16}$ The Bern Convention has shaped

14 REEVE, Rosalind Policing international trade in endangered species: The CITES treaty and compliance. London: Earthscan, 2002, WYATT, Tanya. Is CITES Protecting Wildlife? Assessing Implementation and Compliance. London and New York. Earthscan Routledge, 2021.

${ }^{15}$ CITES has 183 parties including the EU as one party and the Bern Convention has 55 member states.

16 LIBERG, Olof, et al. Shoot, shovel and shut up: cryptic poaching slows restoration of a large carnivore in Europe. Proceedings of the Royal Society B: Biological Sciences, 2012, 279.1730: 910915, TROUWBORST, Arie.. Managing the carnivore comeback: International and EU species protection law and the return of the lynx, wolf and bear to Western Europe. Journal of Environmental Law, 2010, 22(3), 347-372. 
the 55 state parties' legislation and wildlife management, and consequently the killing of wolves, for instance, may now be a punishable offence in Norway. ${ }^{17}$ In Norway, illegal hunts of endangered predators have become an environmental crime foreseen by the criminal codes and statutes, which should thereby be prioritized ${ }^{18} \mathrm{At}$ the same time, $\S 17$ of the Norwegian Nature Diversity Act, which is also a response to international obligations to protect 'nature', opens up the possibility that such killings will not be punished if they are carried out to protect livestock. ${ }^{19}$

That CITES regulates, rather than prohibits trade, creates the problem of parallel legal and illegal markets, e.g., illegal ivory can be laundered and wild-caught animals passed as having been bred in captivity ${ }^{20}$. There may be inherent contradictions in the implementation and enforcement of CITES because laws concerning wildlife privilege the interests of humans yet aim to balance these with wildlife conservation. Therefore, in some instances, hunting and collecting endangered species may be simultaneously licensed and criminalized.

The authorities must balance their obligation to preserve biodiversity and ecosystems with public interests of specific importance ${ }^{21}$ or the interests of farmers, hunters, and meat producers ${ }^{22}$. Central to this research, therefore, is the question whether CITES and the Bern Convention send mixed signals. This is a serious

\footnotetext{
${ }^{17}$ Norwegian verdicts regarding such crimes suggest a move towards stricter punishment by the legal system. On 20 April 2015, in Sør-Østerdal District Court, five men were convicted of the illegal killing of a wolf. Sentences included prison terms of up to 1 year and eight months. The case was appealed and ended in the Supreme Court where the offenders were convicted and sentenced to up to oneyear terms of imprisonment.

${ }_{18}$ BUSCH, Tor-Aksel. Mål og prioriteringer. Etterforsking av miljøkriminalitet. 2015. Miljøkrim 1, http://www.okokrim.no/miljokrim/nor/tidligere-utgaver/1_mai_2015/artikler/ra-mal-prioriteringer Politidirektoratet Tendenser i kriminaliteten. Utfordringer i Norge. Oslo: Politidirektoratet. (2014).



20 FAJARDO, T. 2016, SOLLUND, R.2019, VAN UHM. D. 2016, Warchol, G., Zupan, L., \& Clarke, W. (2003). Transnational criminality: An analysis of the illegal wildlife market in southern Africa. International Criminal Justice Review, 13(1), 1-26.

${ }^{21}$ Court decision from Oslo Tingrett 5 Jan.2018 (17-196251TVI-OTIR/08)

${ }^{22}$ LINNELL, J. D., TROUWBORST, A., \& FLEURKE, F. When is it acceptable to kill a strictly protected carnivore? Exploring the legal constraints on wildlife management within Europe's Bern convention Nature Conservation, 2017. 21:129-157, SKOGEN, K., KRANGE, O., \& FIGARI, H. (2013). SOLLUND, Ragnhild. With or without a license to kill: Human-predator conflicts and theriocide in Norway. In A. Brisman, N. South, \& R. White (Eds.), Environmental crime and social conflict: Contemporary and emerging issues. Farnham, UK: Ashgate, 2015c.
} 
concern because the implementation of the conventions may not have the desired effect if they are not consistently implemented ${ }^{23}$.

The international legal framework for protecting endangered predator species is intended to exert a decisive influence on the options available to public authorities in responding to growing predator populations, ${ }^{24}$ yet states regularly license hunts of large endangered predators, which may be a breach of the Bern Convention and CITES. This suggests endangered animal species and biodiversity are not protected in law as having intrinsic value. ${ }^{25}$ Rather, the foundation of international protection, especially of CITES, is anthropocentric and as such may expand the consequences of the Anthropocene-the goal of CITES is to ensure the survival of species so that humans can continue to exploit animals as "resources".

The emphasis of the Bern Convention can also be interpreted as anthropocentric. It highlights wildlife as a 'natural heritage of aesthetic, scientific, cultural and recreational value, yet acknowledging that wild fauna and flora have intrinsic value' (Council of Europe, n.d. in Preamble). Then, it is in humans' self-interest to preserve species, but the intrinsic value of fauna must be balanced against human interest. Again, this can result in mixed, even contradictory, signals being communicated in law enforcement. ${ }^{26}$ Culling of wolves, as a measure meant to protect them from illegal killing through satisfying wolf adversaries, may increase illegal killing, rather than reducing it. ${ }^{27}$

That wildlife management is anthropocentric may have consequences for a possible lack of respect that is paid to the individual welfare of free born animals and an aim of CRIMEANTHROP is to investigate the role of conventions in facilitating or preventing such lack of respect, through a harm approach. The process of abduction of wildlife when the intention is for them to survive, may, whether legal or illegal,

${ }^{23}$ FAJARDO, T: this special issue, GOYES \& SOLLUND 2016, WYATT, T: 2021

${ }^{24}$ E.g. TROUWBORST, A. 2010),

${ }^{25}$ REGAN, T. 2010).

${ }^{26}$ SOLLUND, R. 2015C).

${ }^{27}$ CHAPRON, Guillaume; TREVES, Adrian. Blood does not buy goodwill: allowing culling increases poaching of a large carnivore. Proceedings of the Royal Society B: Biological Sciences, 2016, 283.1830: 20152939. 
cause severe trauma and abuse, and when trafficked very many animals die during capturing or shortly thereafter. Further, although CITES provides suggestions concerning the care of seized and confiscated animals, many countries may have failed to articulate and practice appropriate solutions concerning the welfare of these animals. ${ }^{28}$ During hunts animals are often severely injured, and therefore suffer much before they eventually die. ${ }^{29}$ Whether such acts are crimes in a legal sense or 'just harms', from an animal rights perspective and in terms of species justice ${ }^{30}$, they are morally questionable ${ }^{31}$. Wildlife management may have little concern for animal welfare, when in Norway, wolverine pups may be killed in front of their mother, unwanted predators are hunted by means of helicopters, and breeds of foxes deemed wrong are systematically killed. ${ }^{32}$ Whether such examples are due to preconvention practice, and whether this is in concordance with or despite the Bern convention, is a topic for this research.

Animal welfare has been incorporated to some degree in the legislation of most countries as a consequence of the growth of the contemporary animal rights movement ${ }^{33}$, and some are rather ambitious in according animals intrinsic value (e.g. $\S 3$ of the Norwegian Animal Welfare Act). Yet despite this and much research on the cognitive and sentient capacities of animals ${ }^{34}$, the anthropocentrism of animal welfare legislation is clear. The intrinsic value of animals is often counteracted by

\footnotetext{
28 Sollund, R. \& Maher, J. 2016.

29 STOKKE, Sigbjørn., \& ARNEMO, Jon. M. (2014). Hvor langt løper en skadeskutt rein? Norsk Veterinærtidsskrift, 126(2), 258-261.

30 E.g. WHITE,R. 2013)

31 SEGALL, Shlomi; NUSSBAUM, Martha C. Frontiers of Justice: Disability, Nationality, Species Membership. Utilitas, 2009, 21.4: 526., RAMP, Daniel; BEKOFF, Marc. Compassion as a practical and evolved ethic for conservation. BioScience, 2015, 65.3: 323-327. VETLESEN, Arne Johan. The denial of nature: Environmental philosophy in the era of global capitalism. Routledge, 2015.

32 SOLLUND, R. (2012). Speciesism as doxic practice versus valuing difference and plurality. In ELLEFSEN, R., SOLLUND, R. AND \& G. LARSEN (EDS) Eco-global crimes. Contemporary problems and future challenges.(pp.91-115). Farnham: Ashgate, 2012.

33 BEIRNE, P. Confronting animal abuse: Law, criminology, and human-animal relationships. Lanham:Rowman \& Littlefield, 2009. FRANCIONE, Gary. Animals as persons. New York: Columbia University Press., 2008, NIBERT, D. 2002, REGAN. T. 2010, SINGER, P. 1995)

BEKOFF, Marc. Animal emotions and animal sentience and why they matter: Blending "science sense" with common sense, compassion and heart. Earthscan Publishing: London, UK, 2006, Bekoff, M., \& Pierce, J. (2009). Wild justice: Honor and fairness among beasts at play. In Wild justice: The moral lives of animals. University of Chicago Press, PEPPERBERG, Irene M. The Alex studies: cognitive and communicative abilities of grey parrots. Harvard University Press, 2009
} 
human interest, for example, wild animals may be given importance only as members of a species ${ }^{35}$ and to the extent that this species is endangered, as when elephants are acknowledged as an aspect of 'world heritage'. ${ }^{36}$ The balancing of different obligations and interests seems to be key to understanding how this is possible. An important topic that needs investigation, is if the contradictory purposes of national laws' implementation of CITES and Bern conventions also will have contradictory results concerning animal protection. The Animal Welfare Act and the Wildlife Law in Norway have different purposes but are both central in setting rules for the treatment of animals in this country; the first is to ensure the protection of individual animals, the second preponderantly establishes the requirements and conditions for how/when wildlife can be killed. Are the effects of the common anthropocentric phrasing in both acts; that animals shall not be subject to unnecessary suffering (the Wildlife Law) or unnecessary strain that in reality these laws totally fail in protecting free born animals' individual lives and welfare, like is already assumed in relation to the CITES and Bern conventions?

\section{RESEARCH QUESTIONS AND RATIONALE OF CRIMEANTHROP}

CRIMEANTHROP examines three overarching research questions we regard as central to the above, exploring the foundation, implementation, practices, and consequences of current wildlife conservation through interviews and document analyses, depending on available data sources in each country and the researchers' disciplinary background.

Hypothesis I: Because the messages of CITES and the Bern Convention are ambiguous concerning wildlife protection and animal welfare; consequently so are regulation/legislation and implementation. This project assumes that the ambiguity in socio-legal norms of and approaches towards nature management, the

35 SOLLUND, Ragnhild. Animal trafficking and trade: Abuse and species injustice. In: alter, R., Westerhuis, D. and Wyatt, T. (Eds). Emerging issues in green criminology. Palgrave Macmillan, London, 2013, SOLLUND, Ragnhild. (2017). Perceptions and law enforcement of illegal and legal wolf killing in Norway: organized crime or folk crime?. Palgrave Communications, 3, 17059.

${ }^{36}$ STRAHM, Wendy. (2008). World heritage and the IUCN red list. World Heritage 49, 18-29. 
interests of wildlife, human interests, and the ways in which these are balanced in CITES and the Bern Convention are reflected also in state policies. ${ }^{37}$ While wildlife (seen as species) is accorded value and protection in the conventions, this does not filter down to the individual level, resulting in a discrepancy between the protection that animals are accorded in legislation and actual practice. The intrinsic value of each animal as established in legislation and the Bern Convention may thereby be overridden by the priority given to human interest, the survival of species and the protection of nature's biodiversity, resulting in a justification for killing individual animals. Such ambiguities exist in policy and in verdicts connected to the enforcement of national legislation related to CITES and the Bern Convention.

Hypothesis II: The unclear normative messages conveyed by CITES and the Bern Convention hinder their implementation and compliance as well as the achievement of further goals such as awareness raising, wild life conservation, and ecosystem protection. Mixed normative signals may create confusion in society and among potential offenders such as consumers of wildlife and hunters ${ }^{38}$. Wildlife trade is both legal and illegal, an administrative issue and a criminal offence; killing endangered predators is both legal and illegal, and what used to be permitted and taken for granted or even rewarded, for example, shooting predators, has become relatively prohibited. This means it has been regulated under unclear circumstances that can vary or be modified. Ambiguity in the conventions and the ways in which international binding and non binding dispositions (legal and nonlegal) norms are translated into national norms may be related to the identity of the norm entrepreneurs who integrate international norms at the local levels. The transfer of norms varies in different geographical and political contexts, and therefore such processes need to be identified and explored. This issue remains to be explored in future publications. The complexity of the legal systems required to implement CITES and the Bern Convention and the uncertainty that this creates have been critiqued both by citizens and law enforcement agencies. How such ambiguities play out needs to be empirically investigated within a framework capable

\footnotetext{
${ }^{37}$ Because Norway is not an EU member, The European Habitat Directive will not be analysed in Norway.

38 GOYES, D.R. and \& SOLLUND, R. 2016, SOLLUND, R. 2015 c
} 
of delineating the relationship between legal and social norms and actions as well as how citizens, NGOs, law enforcement agencies, and the judicial system affect, disseminate, and comply with them. While these conventions have shaped national policy development and implementation in Member States, including normative and legal changes that are traceable and communicated through policy development, legislation, and enforcement, CITES and the Bern Convention only relatively criminalise the exploitation and hunting of endangered animal species. This may convey an unclear normative message.

Hypothesis III: Conventions are formulated in ways that give room for discretion and different interpretation in order to achieve that states with different interests join the agreements. There are thus differences in how political decisions concerning wildlife management are generated and their outcomes, meaning that states in different ways comply with the goals of wildlife conservation set in the CITES and the Bern Convention. This means differences in practices concerning the integration of individual and species protection and justice are integrated into states' conservation efforts. Many policy fields are filled with contradictions and ambiguities, and it is necessary to empirically assess and theoretically explore in each case what these are and the consequences they produce. While Member States sign the same conventions, their implementation and enforcement of these conventions perforce may vary because of their very different domestic law-making processes and the different interpretations of what the legal implications of the treaties entail.

\section{PRESENTATION OF THE ARTICLES IN THIS SPECIAL ISSUE}

David Rodríguez Goyes is a post.doc. fellow at CRIMEANTHROP. His tasks in the project is, amongst others, to specifically explore the philosophical foundations of CITES and the Bern convention. His article; Contending philosophical foundations in international wildlife law: a discourse analysis of CITES and the Bern convention, relates directly to the hypotheses of the project concerning the ambiguities in the conventions and their deficits in providing clear normative and legal guidance to the 
parties of the conventions. These ambiguities impact directly on their capacity to provide endangered wildlife the protection they need.

He finds that the philosophical underpinnings of these instruments are in contention, indicating that their policies might well counteract each other. The consequences of this contention is a resulting ambivalence concerning the instruments established to protect wildlife resulting in so high discretional powers for states that they stop being bounded by the conventions' substratum and can limit themselves to only following the formalities. This is for example witnessed in relation to the protection of large carnivores in Norway, that is zone based and decreasing, through which this predator zones are no longer respected. Goyes finds that the philosophical ambivalence of IWL instruments, which allows states an array of acceptable philosophical pillars, when combined with the permanent sovereignty doctrine, which strengthens the state's decisional freedom, removes from the conventions the ambitious commitment that inspired them and mainly leaves a formalistic shell. Consequently, the philosophical ambivalence of CITES and the Bern Convention goes a long way to explain their suboptimal performance: while commentators expect that they offer real protection to wildlife, they fall prey to "legal fetishism". This is a serious accusation and gloomy description of the implementation of the conventions that are intended to protect wildlife. The other articles in this special issue explores to which degree this grim picture is supported in the empirical research in Norway, Germany, the UK and Spain.

Tanya Wyatt's article, CITES and the Bern Convention in the UK: an exploration of norms and ambiguities, is not encouraging, in terms of implementation and enforcement of the two conventions. This is studied by means of empirical data in form of interviews and the study of paperwork related to CITES and Bern convention. She incorporates to her study the issue of animal welfare, so central to CRIMEANTHROP, and employs a mixed-methods study including content analysis of convention documentation and semi-structured interviews. She finds that whilst the UK has a reputation for actively engaging in wildlife conservation and being a nation of animal lovers, management of its own wildlife is under resourced and could be improved. Wyatt founds further that there is a lack of dialogue about the core 
ethical issues regarding wildlife trade and consumption. As witnessed before in relation to wildlife crime and law enforcement in Norway, the fact that wildlife is constituted by individual sentient animals with interests seems to vanish from the rhetoric and rationale determining the implementation of such legislation. Wyatt exemplifies UK's failure to fully comply with the conventions, stating that the UK biennial reports of CITES and the Bern Convention support the contention that the UK approach to wildlife conservation is to prioritise wildlife in other parts of the world. Research and funding of research on the illegal wildlife trade are concentrated abroad and not focused on the consumption of wildlife taking place in the UK, neither in terms of native or non-native wildlife nor of wildlife imported or exported. The killing of tens of thousands of badgers which is a Bern-listed species in the UK is glossed over. The Bern documentation in particular evidences this state theriocide not only of badgers, who are targeted by the ongoing cull, but of bats as well through their routine destruction during human construction projects. While building the country's reputation as a protector of wildlife internationally, the UK shields itself from being held accountable for violating international conventions, and protects the economic interests in conflict with wildlife conservation (i.e., agriculture and construction). Wyatt thus states that, trying to expect the inclusion of or to add on species justice and welfare to the existing structures appears to be a step too far for the stakeholders as well as the legislative structures in the UK.

Christoph Stefes' article, Wildlife protection in Germany: sound legislation and deficient implementation, investigates the implementation of wildlife regulations pertinent to EU law and the Bern convention in Germany. He finds that Germany has comprehensively codified into national legislation numerous international and regional treaties. Furthermore, European Union regulations are directly binding in its Member States. Yet Germany's implementation of wildlife protection laws remains wanting, there is what Stefes refers to as an implementation gap between the country's comprehensive legal framework and related enforcement. This, however, is not only because of the ambiguities of the framework of the conventions and nation states' discretionary power in their interpretation and implementation of international conventions, but due, not the least, to Germany's decentralized administrative 
structure embedded in its federal system. This prevents a centralized enforcement and requires a more coordinated approach to narrow the gap between Germany's legislation and enforcement. For example, the delegation of authority down to the lowest level of Germany's administrative apparatus has caused a wasteful decentralization of authority over the enforcement of wildlife legislation with resources spread thin. Officials at lower administrative levels, including judges and prosecutors, are unable to accumulate sufficient expertise, and they lack sufficient training. Consequently; despite Germany being party to the Bern convention and stronger EU law, wildlife protection is insufficiently effectuated, and if punishment is applied for wildlife offenses, they are lenient. Stefes thus adds to the picture of deficient implementation and enforcement if the conventions found in the UK. The fact that this lack of enforcement was due to Germany's decentralized administrative structure embedded in its federal system was an unforeseen finding, which serves to emphasise the importance of grounded empirical, interdisciplinary research.

Ragnhild Sollund's article: The development of enforcement of CITES in Norway: discretionary omissions and theriocides, likewise demonstrates that while legislation is in place and that the country formally complies to CITES, discretionary decisions - what is referred to as anthropocentric, discretionary harms of omission in law enforcement - are made by law enforcement agents in police, customs and within judicially powers which entail breaches of CITES are leniently, even paradoxically enforced. The article is based on data collection constituted by qualitative interviews and the analyses of penal case file material done in several stages, and traces how crimes of wildlife trade are addressed by law enforcement agencies in a longitudinal perspective. While in the first stages of her research Sollund found out that animal victims of trafficking would often be killed by the authorities in Norway if they could not be rehomed in a Zoological garden, now this practice is turned into state policy. Taking a species justice approach and based on a discussion of possible changes and development in enforcement in Norway, this article argues that this crime is still insufficiently prioritized by enforcement agencies. Weak points identified at the early stages of this research, in 2010-2013, such as deficient recording of CITES crimes and discretionary lack of priority of investigation, were still existent in 2020. The most 
serious weakness is the policy of killing confiscated animals pertaining to endangered species, which is a considerable breach of species justice.

Teresa Fajardo del Castillo's article; Wolf (dis)protection in Spain: Exceptions to the rules in the Bern Convention and in the Habitats Directive as a conservation and management tool, explores the implementation of the Bern convention in Spain, while comparing the situation here to that of other European countries in northern Europe. She focusses on the protection or lack of protection of wolves and how this is implemented or fails to be implemented in relation to the Bern convention and the Habitat's directive, through empirical data in form of interviews and the study of case law and other relevant paperwork. The announcement made in 2021 that Spain was going to ban wolf hunting throughout its territory became the trigger to reopen the debate on the wolf and its conservation and management status. In Europe, the unexpected success of wolf conservation policies which allowed the wolves to return to territories wherefrom they were previously banned, has led to the wolf being considered as a "pest" or a species detrimental to agriculture and livestock farming. This perception of predators is present in and inspires the reservations and exceptions to the rules of the Bern Convention and those of the Habitats Directive of the European Union, which provide for different protection statuses and management regimes, such as in Norway, Sweden, Finland, Germany and Spain. Exceptions to these rules allow some states to prohibit wolf hunting and others to allow it in order to avoid escalating conflicts with humans. Although this 'rule of law of biodiversity', guarantees legal protection for the wolf, in practice a serious lack of compliance has been revealed, which is one of the threats to the wolf. A study of the application of these exceptions in Spain and the case law of the Spanish courts and the Court of Justice of the European Union suggests that the legalisation of hunting, a strategy which is used e.g. also in Finland, Norway and Sweden to reduce conflict over the return of the wolves, cannot serve to remedy this compliance deficit when there are alternatives. These may include criminal or administrative prosecution of violations.

The article of Martine S.B. Lie; "Humane theriocides": traces of compassion for animals in the Norwegian legal discourse on illegal bear and wolf killings, Lie 
focusses on the violations of laws implanted for Norway to comply with the Bern convention, and explores how such crimes are treated in the judicial system. The populations of wolves and brown bears are approximately 100 and 150 individuals, respectively. Numbers are kept low through licensed hunts. These animals are also vulnerable to illegal theriocides (killings of animals by humans), which, as mentioned, pose a considerable threat to the species' survival. The theriocides also harm individual animal victims and impinge on their intrinsic value. Lie's article assesses whether a consideration of harm to the individual animals is part of the Norwegian courts' problem definition and discourse order regarding such illegal hunts by developing and conducting a "critical green victimological discourse analysis" of verdicts. Moreover, the courts' portrayals of the victims are assessed-by asking the question: do they acknowledge them as such, or continue the speciesist ideology of the Anthropocene, seeing animals mainly as commodities and components of nature? Lie finds that the hegemonic problem definition of the (attempted) theriocides are described in the verdicts as breaches of species conservation principles, rather than breaches of animal rights. If describing victims -the animals and harm afflicted on them through the crimes, the discourse represented is one of species conservation, highly focussed on genetics and reproduction. This represents an environmental justice perspective that dominates the verdicts, rather than a species justice perspective. The focus is on preserving nature and the animals living there for human purposes, rather than in their own right.

To briefly sum up: The hypotheses and research questions of CRIMEANTHROP have to large degree been confirmed by empirical research and clearly underline that the ways in which CITES and the Bern convention are implemented and enforced to little degree serve to provide free born animals of endangered species the necessary protection. On the positive side, there has been a return of wildlife in Europe, which can indicate rewilding, but the interests of these animals are at stake and easily exchanged for human interest, such as the keeping of domesticated animals for meat production and hunting. The ambiguities of the text of the conventions and in its underlying foundation and the discretion nation states parties to the conventions - have in setting their own rules and advance their own 
interests in the interpretation of the conventions, entail theses are implemented and enforced in different ways in the countries involved in the CRIMEANTHROP research. The ambiguities in the implementation of the conventions also entail that animals of endangered species become victims of unlawful killings, due to lack of normative signals that could have been conveyed had the conventions and hence pertaining legislation been properly implemented and enforced. The enforcement of the conventions leave little room for consideration of individual animal rights or animal welfare that are sacrificed for an unjustified belief in the letter of the law. Animals of endangered species are regarded simply as a component of a species, rather than as an individual with interests.

The issue of how norm entrepreneurs affect the implementation and enforcement of the conventions in different countries will be explored in future CRIMEANTHROP research.

\section{ACKNOWLEDGEMENTS}

I want to thank Antoni Pigrau and Victor Merino Sancho, the editor-in-chief and the editor of The Catalan Journal of Environmental Law, for giving me the opportunity to edit this special issue of the journal in order to present the research from CRIMEANTHROP, and for all their support and valuable help throughout the process. I also want to extend my gratitude to all the reviewers of the articles for their contributions to improve the quality of our work. Thank you also to the contributors to the special issue, Teresa Fajardo del Castillo, Christoph Stefes, Tanya Wyatt, Martine S.B. Lie and David R. Goyes, as well as to the advisory board of the project, Avi Brisman and Nigel South.

\section{REFERENCES}

AGNEW, Robert. (Dire forecast: A theoretical model of the impact of climate change on crime. Theoretical Criminology, 2012).16(1),21-42.

BENTON, Ted. Rights and justice on a shared planet: More rights or new relations. Theoretical Criminology, 1998. 2(2), 149-175. 
BEIRNE, Piers. For a nonspeciesist criminology: Animal abuse as an object of study. Criminology, 1999 37(1), 117-148.

BEIRNE, Piers. Confronting animal abuse: Law, criminology, and human-animal relationships. Lanham: Rowman \& Littlefield, 2009.

BEIRNE, Piers., \& SOUTH, Nigel. Approaching green criminology. In P. Beirne \& N. South (Eds.), Issues in green criminology: Confronting harms against environments, humanity, and other animals (pp. xiii-xxii). 2007. Cullompton, UK: Willan Publishing. BEKOFF, Mark. Animal emotions and animal sentience and why they matter: Blending 'science sense' with common sense, compassion and heart. London: 2006. Earthscan Publishing.

BEKOFF, Mark., \& Pierce, JESSICA. Wild justice: Honor and fairness among beasts at play. In Wild justice: The moral lives of animals. 2009. University of Chicago Press. BUSCH, Tor-Aksel. Mål og prioriteringer. Etterforsking av miljøkriminalitet. 2015. Miljøkrim $\quad 1, \quad$ http://www.okokrim.no/miljokrim/nor/tidligereutgaver/1_mai_2015/artikler/ra-mal-prioriteringer

Chapron, Guillaume., \& Treves, Adrian. Blood does not buy goodwill: Allowing culling increases poaching of a large carnivore. 2016. Proceedings of the Royal Society $B$ 283: 20152939. http://dx.doi.org/10.1098/rspb.2015.2939

Council of Europe. (n.d.). Convention on the Conservation of European Wildlife and Natural Habitats, Bern 19.IX.1979 Accessed on 18 April 2017, from http://www.coe.int/en/web/conventions/full-list//conventions/rms/0900001680078aff

Crutzen, P. J. The anthropocene. 2002. Journal de pyhisique 12, 1-5.

CITES https://cites.org/eng Accessed on 21 April 2021

CITES https://cites.org/eng/disc/how.php Accessed on 21 April 2021

CITES Resolution https://cites.org/eng/res/10/10-07R15.php Accessed on 21 April 2021 
European Commission. The EU approach to combat wildlife trafficking. http://ec.europa.eu/environment/cites/trafficking en.htm, 2014. Accessed on 21 June 2021

FAJARDO, Teresa. The European Union's approach in the fight against wildlife trafficking: Challenges ahead. Journal of International Wildlife Law and Policy, 2016. 19(1), 1-21.

FRANCIONE, Gary. Animals as persons. New York: Columbia University Press., 2008.

GOYES, David; SOLLUND, Ragnhild. Contesting and contextualising CITES: Wildlife trafficking in Colombia and Brazil. International Journal for Crime, Justice and Social Democracy, 2016, 5.4: 87.

GOYES, David Rodríguez; SOLLUND, Ragnhild. Animal abuse, biotechnology and species justice. Theoretical Criminology, 2018, 22.3: 363-383.

HALSEY, Mark; WHITE, Rob. Crime, ecophilosophy and environmental harm. Theoretical criminology, 1998, 2.3: 345-371.

HARARI, Yuval Noah. Sapiens: A brief history of humankind. London: Vintage Books,2015.

HUTTON, Jon; DICKSON, Barnabas (ed.). Endangered species, threatened convention: the past, present and future of CITES, the Convention on International Trade in Endangered Species of Wild Fauna and Flora. London, UK: Earthscan, 2000;

LOV OM NATURENS MANGFOLD [LAW OF NATURE DIVERSITY]. LOVDATA. https://lovdata.no/dokument/NL/lov/2009-06-19-100/KAPITTEL 3\#\%C2\%A726 Accessed on 21 April 2021

Lovdata 2002). https://lovdata.no/dokument/SF/forskrift/2002-11-15-1276 Accessed on 22.May 2017. 
LIBERG, Olof, et al. Shoot, shovel and shut up: cryptic poaching slows restoration of a large carnivore in Europe. Proceedings of the Royal Society B: Biological Sciences, 2012, 279.1730: 910-915.

LINNELL, John; TROUWBORST, Arie; FLEURKE, Floor. When is it acceptable to kill a strictly protected carnivore? Exploring the legal constraints on wildlife management within Europe's Bern convention. In: Exploring the Legal Constraints on Wildlife Management within Europe's Bern Convention (September 13, 2017). 2017. p. 129-157.

LYNCH, Michael J.; STRETESKY, Paul B. Exploring green criminology: Toward a green criminological revolution. Ashgate Publishing, Ltd., 2014

LYNCH, Michael J.; GENCO, Leo. Animal abuse registries: expanded interest in animal protection mimics other criminal justice policies, but should green criminologists hop on the band-wagon? Contemporary Justice Review, 2018, 21.4: 351-370

MAHER, Jennifer; SOLLUND, Ragnhild. Law enforcement of the illegal wildlife trafficking: a comparative strengths, weaknesses, opportunities and threats analysis of the UK and Norway. Journal of Trafficking, Organized Crime and Security, 2016, 2.1: $82-99$

NIBERT, David. Animal rights/human rights: Entanglements of oppression and liberation. Rowman \& Littlefield Publishers, 2002

NURSE, Angus. Policing wildlife. Perspectives on the enforcement of wildlife legislation. Basingstoke: Palgrave. 2015

PEPPERBERG, Irene M. The Alex studies: cognitive and communicative abilities of grey parrots. Harvard University Press, 2009

Politidirektoratet Tendenser $i$ kriminaliteten. Utfordringer $i$ Norge. Oslo: Politidirektoratet. (2014).

RAMP, Daniel; BEKOFF, Marc. Compassion as a practical and evolved ethic for conservation. BioScience, 2015, 65.3: 323-327. 
REGAN, Tom. (2010). The case for animal rights. Berkeley: University of California Press.

REEVE, Rosalind Policing international trade in endangered species: The CITES treaty and compliance. London: Earthscan, 2002.

SHEARING, Clifford. (2015).Criminology and the anthropocene. Criminology and Criminal Justice, 15(3), 255-269.

Schneider, Jacqueline L. (2012). Sold into extinction: The global trade in endangered species. Santa Barbara, CA: Praeger.

SEGALL, Shlomi; NUSSBAUM, Martha C. Frontiers of Justice: Disability, Nationality, Species Membership. Utilitas, 2009, 21.4: 526.

SINGER, P. (1995). Animal liberation. New York: Random House.

SKOGEN, Ketil., KRANGE, Olve., \& FIGARI, Helene. Ulvekonflikter. En sosiologisk studie. Oslo: Akademika forlag, 2013

SOLLUND, Ragnhild. Expressions of speciesism: The effects of keeping companion animals on animal abuse, animal trafficking and species decline. Crime, law and social change, 2011, 55.5: 437-451

SOLLUND, Ragnhild. Speciesism as doxic practice versus valuing difference and plurality. Eco-Global Crimes, 2012.

SOLLUND, Ragnhild. Animal trafficking and trade: Abuse and species injustice. In: alter, R., Westerhuis, D. and Wyatt, T. (Eds). Emerging issues in green criminology. Palgrave Macmillan, London, 2013

SOLLUND, Ragnhild (ed.). Green harms and crimes: Critical criminology in a changing world. Springer, 2015.

SOLLUND, Ragnhild. (Introduction: Critical, green criminology-An agenda for change. In R. Sollund (Ed.), Green harms and crimes: Critical criminology in a changing world (pp. 1-27). Basingstoke, UK: Palgrave Macmillan, 2015b

SOLLUND, Ragnhild. With or without a license to kill: Human-predator conflicts and theriocide in Norway. In A. Brisman, N. South, \& R. White (Eds.), Environmental 
crime and social conflict: Contemporary and emerging issues. Farnham, UK: Ashgate, 2015c.

SOLLUND, Ragnhild. (2017). Perceptions and law enforcement of illegal and legal wolf killing in Norway: organized crime or folk crime? Palgrave Communications, 3 , 17059.

SOLLUND, R. The crimes of wildlife trafficking. Issues of justice, legality and morality. London and New York: Routledge, 2019.

SOLLUND, Ragnhild., TØNNESSEN, Morten, \& LARSEN, Guri. Hvem er villest $i$ landet her? Råskap mot dyr og natur $i$ antropocen, menneskets tidsalder. Oslo: Spartacus SAP, 2013

South, N. Anticipating the Anthropocene and greening criminology. Criminology \& Criminal Justice, (2015). 15(3), 270-276.

SOLLUND Ragnhild, MAHER Jennifer (2015) Illegal wildlife trade. A case study on illegal wildlife trade in the United Kingdom, Norway, Colombia and Brazil. Report produced as part of EFFACE. Available at: http://efface.eu/illegalwildlife-trade-casestudy-report-illegal-wildlife-trade-united-kingdom-norway-colombiaand\#overlaycontext=case-studies Accessed 21 April 2021

SOUTH, Nigel. (2015). Anticipating the Anthropocene and greening criminology. Criminology \& Criminal Justice, 15(3), 270-276.

STRAHM, W.. World heritage and the IUCN red list. 2008, World Heritage 49, 1829.

STRAUSS, Anselm., \& CORBIN, Juliet. (1994). Grounded theory methodology. Handbook of qualitative research, 17, 273-285.

STRETESKY, Paul. B., LONG, Michael. A., \& LYNCH, Michael. J. The treadmill of crime: Political economy and green criminology. Routledge, 2013)

STRAUSS, Anselm., \& CORBIN, Juliet. Grounded theory methodology. Handbook of qualitative research, 17, 273-285, 1994 
TROUWBORST, Arie.. Managing the carnivore comeback: International and EU species protection law and the return of the lynx, wolf and bear to Western Europe. Journal of Environmental Law, 2010, 22(3), 347-372.

Trouwborst, Arie. Global large carnivore conservation and international law. Biodiversity Conservation, 2015, 24, 1567-1588.

VAN UHM, Daan Uncovering the illegal wildlife trade: In the world of poachers, smugglers and traders. New York: Springer, 2016.

VETLESEN, Arne. Johan (2015). The denial of nature: Environmental philosophy in the era of global capitalism. London: Routledge.

WHITE, Rob. Environmental harm: An eco-justice perspective. Policy Press, 2013.

WYATT, Tanya. Wildlife trafficking: A deconstruction of the crime, the victims and the offenders. Basingstoke, UK: Palgrave, 2013

WYATT, Tanya. Is CITES Protecting Wildlife? Assessing Implementation and Compliance. London and New York. Earthscan Routledge. 2021.

WWF (2020) Living Planet Report 2020 - Bending the curve of biodiversity loss. Almond, R.E.A., Grooten M. and Petersen, T. (Eds). WWF, Gland, Switzerland. 